\title{
Persistent genotypic differences in mouse activity under unusually varied circumstances'
}

D. D. THIESSEN

SCRIPPS CLINIC AND RESEARCH FOUNDATION, LA JOLLA

\begin{abstract}
Abstraet
Twenty-one comparisons of activity differences among C57, DBA and C3H strains of mice have appeared over the past $11 \mathrm{yr}$. Despite wide variations in the use of substrains, experimental techniques and testing devices, strain rank order remains statistically stable. Such uniformity may indicate well-buffered physiological correlates.

\section{Problem}

The changeable nature of gene action is well known to behavior geneticists. Generally three modes of variation are recognized: (1) differential gene expression contingent on the prevailing genotypic background; (2) diverse canalization of gene action due to environmental pressures during development; and (3) varied responses depending on the level and kind of environmental stimulation. Such diversity of response demonstrates unequivocably gene-environment interaction, but at the same time provides an array of individual variation often difficult to work with experimentally and conceptually. This report summarizes data which are exceptional in that phenotypic differences in behavioral activity among three inbred strains of mice tend to persist under all three sources of variation noted above.
\end{abstract}

\section{Method and Results}

The increasing use of inbred strains of mice for behavioral work made it possible to compile and compare activity data from a variety of sources and conditions of measurement. Available data on spontaneous activity for the $\mathrm{C} 57, \mathrm{DBA}$ and $\mathrm{C} 3 \mathrm{H}$ strains are shown in Table 1. For each of the 21 independent comparisons, the relative standings of the three strains are indicated. The strain showing the greatest amount of activity is arbitrarily assigned the score of 100 and the two other strains are adjusted in value to show their positions relative to the highest strain. In three cases, unequal numbers of substrains within major strain lines were tested (Bruell, 1964a,b; Thompson, 1953); consequently, substrain scores were averaged and used as single scores. Short latencies of response, where applicable, are considered equivalent to high activity.

Sources of animal, experiential and experimental variation are greater than most planned experiments possibly could be. Eight substrains of the C57 line were used, some separated from the original line for nearly 44 yr. Four substrains of the DBA line were tested, some which diverged from the parental stock $35 \mathrm{yr}$. ago. Six substrains of the $\mathrm{C} 3 \mathrm{H}$ stock were observed, again in some cases, with separate breeding histories extending over $35 \mathrm{yr}$. Experiential and experimental variations are just as great. Some investigators applied early noxious stimulation to their animals (Lindzey et al, 1960, 1963); others used alcohol fuming immediately prior to testing (Schlesinger et al, 1962); and one altered population density by 20-fold (Thiessen, 1964). Moreover, the investigators worked on the East and West coasts and the Midwest of the United States over a period of $11 \mathrm{yr}$. Both male and female mice were tested, ranging in age from 30 to 150 days and six different kinds of testing devices were used. Observations of activity varied in length from 3 to $200 \mathrm{~min}$.

Despite wide variations in animal nomenclature and experimental design, relative strain differences tend to be maintained, with the order of activity from high to low, C57, DBA and $\mathrm{C} 3 \mathrm{H}$. For the 21 comparisons, Kendall's Coefficient of Concordance (W) is .59 ( $p<.001)$ for the three strains, $.38(p<.001)$ for the C57 and DBA lines, .18 $(p<.10)$ for the DBA and C3H lines and $1.00(p<.001)$ for the $\mathrm{C} 57$ and $\mathrm{C} 3 \mathrm{H}$ strains. The reversals of the $\mathrm{C} 57, \mathrm{DBA}$ and $\mathrm{C} 3 \mathrm{H}$ rank order are accounted for primarily by reversals between the DBA and $\mathrm{C} 3 \mathrm{H}$ strains. In no instance does the $\mathrm{C} 3 \mathrm{H}$ strain outscore the C57 strain. It would appear that the conditions of testing generally separate the strains in the same order. The obvious exceptions are the data by Lindzey et al $(1960,1963)$, where DBA's show the shortest latency to emerge from a stovepipe. It can be argued that emerging from one environment into another

Table 1. Relative Position of Three Strains of Mice on Various Tests of Spontaneous Activity

Activity Measure
Rotating Wheel
Multiple-Section Maze
Washtub
Washtub
Washtub
Washtub
Washtub
Washtub
Modified Open-Field
Modified Open-Field
Modified Open-Field
Modified Open-Field
Modified Open-Field
Hole-in-Wall
Hole-in-Wall
Hole-in-Wall
Hole-in-Wall
Stovepipe
Stovepipe
Stovepipe
Stovepipe

$\begin{array}{cccc} & \text { Mouse Strain } & & \text { Reference \# } \\ \text { C57 } & \text { DBA } & \text { C3H } & \\ 100 & 97 & 93 & 1 \\ 100 & 93 & 71 & 2 \\ 100 & 68 & 49 & 4 \\ 100 & 81 & 53 & 4 \\ 100 & 41 & 62 & 5 \\ 100 & 58 & 73 & 5 \\ 100 & 94 & 98 & 5 \\ 100 & 56 & 72 & 5 \\ 100 & 75 & 37 & 10 \\ 100 & 89 & 28 & 6 \\ 100 & 60 & 32 & 8 \\ 100 & 53 & 58 & 8 \\ 100 & 95 & 61 & 8 \\ 100 & 65 & 53 & 8 \\ 100 & 33 & 35 & 8 \\ 100 & 30 & 14 & 8 \\ 100 & 24 & 12 & 9 \\ 34 & 100 & 23 & 4 \\ 38 & 100 & 18 & 4 \\ 51 & 100 & 49 & 5 \\ 50 & 100 & 49 & 5\end{array}$


is a matter quite different from the other situations where the animal simply locomotes from one part of an apparatus to another. If these four studies are treated separately, concordance for the remaining conditions jumps to $.77(p<.001)$ for the three strains and $1.00(p<.001)$ for the C57 and DBA strains. The data for stovepipe emergence remain internally consistent. Diseussion

With increasing frequency investigators point to the uniqueness of any behavior and to the complexity of gene-environment interactions. Coupled with this is the growing feeling that each unit of behavior must be studied separately and may only have relevance within the context in which it is studied (Hirsch, 1962). However, multiple instances of stable activity differences between strains of mice suggest that in some instances gene-environment interactions are minimal and that well-buffered physiological systems underlie different levels of behavior. The 21 independent comparisons of spontaneous activity between the C57, DBA and $\mathrm{C} 3 \mathrm{H}$ strains involve at least 11 major differentiating characteristics. Yet rank order separation of strains remains fairly stable, despite breeding separation of the sublines known to affect other genetic differences (Staats, 1964) and despite a variety of experiential and testing differences. Separation is more uniform when emergence tests are considered separately. The latter tests may involve more than activity per se, since animals must move between highly distinctive environments. Differences in activity are also more uniform between the C57 strain and the other two strains than between the DBA and C3H strains. This may be accounted for by the fact that the C57 lines have an origin distinct from that of the other strains, whereas the C3H lines originated in 1920 from a cross between Bagg albino and DBA mice. Thus the $\mathrm{C} 3 \mathrm{H}$ and DBA strains probably share genes in common relevant to activity.
The constancy of gene action under very general conditions may afford a behavioral model for the tudy of physiological correlates that influence activiny $i_{1}$ dependently of specific conditions of testing.

\section{References}

Bruell, J. H. Heterotic inheritance of wheelrunning in mice. $J$. comp. physiol. Psychol., 1964a, 58, 159-163. (1)

BruelI, J. H. Inheritance of behavioral and physiological characters of mice and the problem of heterosis. Amer. Zool., 1964b, 4, 125-138. (2)

Hirsch, J. Individual differences in behavior and their genetic basis. In E. L. Bliss (Ed.), Roots of behavior. New York: Harper, 1962. Pp. 3-23. (3)

Lindzey, G., Lykken, D. T., \& Winston, H. D. Infantile trauma, genetic factors, and adult temperament.J. abnorm. soc. Psychol., 1960, 61, 7-14. (4)

Lindzey, G., Winston, H. D., \& Manosevitz, M. Early experience, genotype and temperament in Mus musculus. J. comp. physiol. Psychol., 1963, 56, 622-629.(5)

Schlesinger, K., \& McClearn, G. E. The effects of alcohol on exploratory activity in six inbred strains of mice. Paper read at Western Psychological Association, San Francisco, Calif., 1962. (6)

Staats, Joan. Standardized nomenclature for inbred strains of mice: third listing. Cancer Res., 1964, 24, 147-168. (7)

Thiessen, D. D. Population density, mouse genotype and endocrine function in behavior. J. comp. physiol. Psychol., 1964, 57, 412-416. (8)

Thiessen, D. D., \& Nealey, Vicki Green. Adrenocortical activity, stress response and behavioral reactivity of five inbred mouse strains. Endocrinol., 1962, 71, 267-270. (9)

Thompson, W. R. The inheritance of behavior: behavioral differences in fifteen mouse strains. Canad. J. Psychol., 1953, 7, 145-155. (10)

\section{Note}

1. This investigation was supported by grant MH-06139 from the National Institute of Mental Health. 